\title{
Bensingtonia thailandica sp. nov., a novel basidiomycetous yeast species isolated from plant leaves in Thailand
}

\author{
1 Japan Collection of \\ Microorganisms, RIKEN, \\ Wako, Saitama 351-0198, \\ Japan \\ 2 Thailand Institute of \\ Scientific and \\ Technological Research, \\ Chatuchak, Bangkok \\ 10900, Thailand
}

\author{
Bundit Fungsin, ${ }^{1,2}$ Makiko Hamamoto, ${ }^{1}$ Vullapa Arunpairojana, ${ }^{2}$ \\ Jiraporn Sukhumavasi, ${ }^{2}$ Poonsook Atthasampunna ${ }^{2}$ and Takashi Nakase ${ }^{1}$
}

Author for correspondence: Makiko Hamamoto. Tel: +8148 467 9560. Fax: +81 484624617. e-mail: hamamoto@jcm.riken.go.jp

\begin{abstract}
Ten strains which were characterized by the formation of ballistoconidia, the absence of xylose in whole-cell hydrolysates, the presence of Q-9 as the major ubiquinone isoprenologue, the inability to ferment sugars and positive diazonium blue $B$ and urease reactions were isolated from plant samples collected in Thailand. These isolates were closely related to Bensingtonia phyllada based on the analysis of 185 rDNA sequences. On the basis of the morphological, physiological and chemotaxonomic properties, the 10 isolates were assigned to the genus Bensingtonia. DNA complementarity showed that these isolates were genetically distinct from known species of the genus Bensingtonia. The isolates are described as Bensingtonia thailandica sp. nov. The type strain is strain TY-138' (= JCM 10651').
\end{abstract}

Keywords: Bensingtonia thailandica sp. nov., ballistoconidium-forming yeasts, basidiomycetous yeasts, $18 \mathrm{~S}$ rDNA

\section{INTRODUCTION}

The genus Bensingtonia was established by Ingold based on a single species, Bensingtonia ciliata (Ingold, 1986). Later, the description of this genus was emended by Nakase \& Boekhout (1988). The genus is characterized by the formation of ballistoconidia, the presence of Q-9 as the major ubiquinone isoprenologue and the absence of xylose in whole-cell hydrolysates (Boekhout \& Nakase, 1998). Ten species are currently known in this genus. The phylogenetic analysis based on 18S rDNA sequences revealed that Bensingtonia species were mainly divided into two groups, the Sporidiales group and the Agaricostilbum/Bensingtonia group, within the Urediniomycetes (Takashima et al., 1995a; Sugita et al., 1997; Hamamoto \& Nakase, 2000).

In the course of a survey of yeasts living in the natural environment in Thailand, 10 strains of undescribed ballistoconidium-forming yeasts were isolated from plant leaves which were collected in a tropical rain forest in Thailand. The identification of these isolates

The DDBJ accession numbers for the $18 \mathrm{~S}$ rDNA sequences of Bensingtonia thailandica strains TY-138', TY-188, TY-191 and TY-223 are AB040114, AB040115, AB040116 and AB040117, respectively. and the description of a new species in the genus Bensingtonia, Bensingtonia thailandica sp. nov., are reported here.

\section{METHODS}

Isolation. Plant samples were collected in a tropical rain forest of Sakearat Environmental Research Station in Nakhon Ratchasima Province, which is the north-eastern region of Thailand, in November 1996. The procedure used for yeast isolation and purification has been described previously (Nakase \& Suzuki, 1985; Nakase \& Takashima, 1993). Ten strains isolated from plant samples (Table 1) were investigated. Bensingtonia ciliata JCM $6865^{\mathrm{T}}$, Bensingtonia miscanthi JCM 5733 ${ }^{\mathrm{T}}$, Bensingtonia phyllada JCM $7476^{\mathrm{T}}$, Bensing tonia subrosea $\mathrm{JCM} 5735^{\mathrm{T}}$ and Bensingtonia yuccicola JCM $6251^{\mathrm{T}}$ were used for the comparative study. All strains were grown at 17 or $25^{\circ} \mathrm{C}$ in yeast extract/malt extract broth or on yeast extract/malt extract agar (Difco) for purification and cultivation.

Morphological, physiological and biochemical characteristics. The isolates were characterized morphologically, physiologically and biochemically by using the method currently used in yeast taxonomy (Yarrow, 1998). Assimilation of nitrogen compounds was examined on solid media with starved inoculum, as described by Nakase \& Suzuki (1986). The vitamin-free medium reported by Komagata \& Nakase (1967) was used for the vitamin requirement test. The medium consists of $1 \%$ glucose, $0.5 \%$ vitamin-free Cas- 
Table 1. List of the isolates used in this study

\begin{tabular}{|llll|}
\hline Isolate & \multicolumn{2}{c}{ Accession no.* } & \multicolumn{1}{c|}{ Source ${ }^{\dagger}$} \\
\cline { 2 - 3 } & JCM & TISTR & \\
\hline TY-138 & $10651^{\mathrm{T}}$ & $5733^{\mathrm{T}}$ & Cratoxylum maingayi \\
TY-173 & 10652 & 5734 & Vitis vinifera \\
TY-180 & 10653 & 5735 & Xylia xylocarpa \\
TY-181 & 10654 & 5736 & Xylia xylocarpa \\
TY-188 & 10655 & 5737 & Seteria pallide-fusca \\
TY-190 & 10656 & 5738 & Seteria pallide-fusca \\
TY-191 & 10657 & 5739 & Seteria pallide-fusca \\
TY-223 & 10658 & 5740 & Dendrolobium triangulare \\
TY-262 & 10659 & 5741 & Boesenbergia pandurata \\
TY-361 & 10660 & 5742 & Pennisetum polystachyon \\
\hline
\end{tabular}

* JCM, Japan Collection of Microorganisms, RIKEN, Saitama, Japan; TISTR, Thailand Institute of Scientific and Technological Research, Chatuchak, Bangkok, Thailand.

$\uparrow$ All strains were isolated from a dead leaf of the species shown at Nakhon Ratchasima, Thailand.

amino acids (Difco), $0 \cdot 1 \% \mathrm{KH}_{2} \mathrm{PO}_{4}, 0 \cdot 05 \% \mathrm{MgSO}_{4} \cdot 7 \mathrm{H}_{2} \mathrm{O}$, $0 \cdot 01 \% \mathrm{NaCl}$ and $0 \cdot 01 \% \mathrm{CaCl}_{2} \cdot 2 \mathrm{H}_{2} \mathrm{O}$, adjusted to $\mathrm{pH} 5 \cdot 5$.

Chemotaxonomy. The presence of xylose in whole-cell hydrolysates was analysed by HPLC as described previously (Suzuki \& Nakase, 1988). Ubiquinones were extracted and purified by the method of Yamada \& Kondo (1973) with slight modifications and determined by HPLC as described previously (Hamamoto \& Nakase, 1995).

Determination of DNA base composition and DNA relatedness. DNA isolation, the determination of $\mathrm{G}+\mathrm{C}$ content by HPLC and DNA-DNA reassociation experiments using the membrane-filter method were carried out as described previously (Hamamoto \& Nakase, 1995).

Nucleotide sequence analyses of 18S rDNA. DNA extraction for PCR and the sequencing of $18 \mathrm{~S}$ rDNA of the representative four isolates (strains TY-138 ${ }^{\mathrm{T}}$, TY-188, TY-191 and TY-223) were performed as described by Hamamoto \& Nakase (2000) with slight modifications. The primers used for amplification and sequencing of $18 \mathrm{~S}$ rDNA, 5.8S rDNA and the internal transcribed spacer (ITS) region were those described by White et al. (1990). The sequences were aligned using CLUSTAL W 1.75 (Thompson et al., 1994) with the selected sequences (Fig. 1) retrieved from the GenBank and DDBJ libraries and manually adjusted. Evolutionary distances were calculated using the PHYLIP $3.57 \mathrm{c}$ program DNADIST (Felsenstein, 1995) with Kimura's two-parameter model and a tree was constructed in NEIGHBOR by the neighbour-joining method (Saitou \& Nei, 1987). The confidence values of branches were determined by performing a bootstrap analysis (Felsenstein, 1985) with 1000 replicates.

\section{RESULTS AND DISCUSSION}

All of our isolates were characterized by the formation of ballistoconidia, whose shapes were ovoid to ellipsoid, the inability to assimilate inositol and to ferment sugars, positive diazonium blue B (DBB) and urease reactions, the absence of xylose in whole-cell hydrolysates and the presence of Q-9 as the major ubiquinone isoprenologue. On the basis of these results, these 10 isolates were assigned to the genus Bensingtonia. They were divided into four groups based on the ability to assimilate galactose, galactitol, D-glucitol and 2-ketogluconic acid: TY-138 ${ }^{\mathrm{T}}$; TY-173, TY-180, TY-181, TY-190, TY-191, TY-262 and TY361; TY-188; and TY-223. Representative strains of each group, strains TY-138 ${ }^{\mathrm{T}}$, TY-188, TY-191 and TY-223, were used for the further investigations.

Long insertions in 18S rDNA were found in strains TY-138 ${ }^{\mathrm{T}}$ (401 nt), TY-188 (377 nt), TY-191 (389 nt) and TY-223 (397 nt) and these were presumed to be introns. The inserted regions of the four strains were considered to be group I introns, because they had conserved sequence elements $\mathrm{P}, \mathrm{Q}, \mathrm{R}$ and $\mathrm{S}$ (Cech, 1988). The sequence of 1713-1805 nt of 18S rDNA was determined for strains TY-138 ${ }^{\mathrm{T}}$, TY-188, TY-191 and TY-223. The levels of $18 \mathrm{~S}$ rDNA sequence similarity among these four strains ranged from 99.8 to $99.9 \%$. The sequence data for these yeasts were aligned with 28 sets of published data. A total of $1424 \mathrm{nt}$ present in all species between positions 99 and 1683 (in Saccharomyces cerevisiae), excluding introns, were used for analysis. Our four isolates formed a cluster together with B. miscanthi, B. phyllada, B. subrosea, $B$. yuccicola and Kondoa malvinella in the Agaricostilbum/Bensingtonia lineage (Hamamoto \& Nakase, 2000), statistically well supported (bootstrap = $100 \%$ ), and closer to B. phyllada than to the other species in this cluster (Fig. 1).

The $\mathrm{G}+\mathrm{C}$ content of the DNA of the representative strains, TY-138 ${ }^{\mathrm{T}}$, TY-188, TY-191 and TY-223, was $47 \cdot 1,47 \cdot 7,47 \cdot 3$ and $47 \cdot 9 \mathrm{~mol} \%$, respectively. They showed high levels of DNA complementarity (76$100 \%$ ) to each other, but strain TY $-138^{\mathrm{T}}$ showed low levels $(5-22 \%)$ of complementarity with the type strains of B. ciliata, B. miscanthi, B. phyllada, B. subrosea and $B$. yuccicola whose $\mathrm{G}+\mathrm{C}$ contents are similar to those of our isolates. These results indicate that our isolates represent a new species of the genus Bensingtonia. The name Bensingtonia thailandica has been proposed for this new species. Table 2 shows the phenotypic characteristics of 11 species of the genus Bensingtonia.

\section{Latin diagnosis of Bensingtonia thailandica sp. nov. Fungsin, Hamamoto \& Nakase}

In medio liquido post dies 3 cellulae vegetativae ovoideae vel ellipsoideae, 2.0-3.0 $\times 5.0-8.0 \mu \mathrm{m}$, singulae aut binae. Post unum mensem pellicula imperfecta et sedimentum formatur. Cultura in agaro YM, albo-cremea, non-nitida, mollis et margine glabra. Hyphae et pseudohyphae non formantur. Ballistospoae reniformes aut ellipsoideae, 3.0-4.0 $\times 7 \cdot 0-8.0 \mu \mathrm{m}$. Fermentatio nulla. Glucosum, galactosum (varium), saccharosum, maltosum, cellobiosum, trehalosum, melibiosum, raffinosum, melezitosum, amylum solubile, glycerolum (varium), galactitolum (varium), D-mannitolum (varium), D-glucitolum (varium), acidum 2-ketogluconicum (varium), 


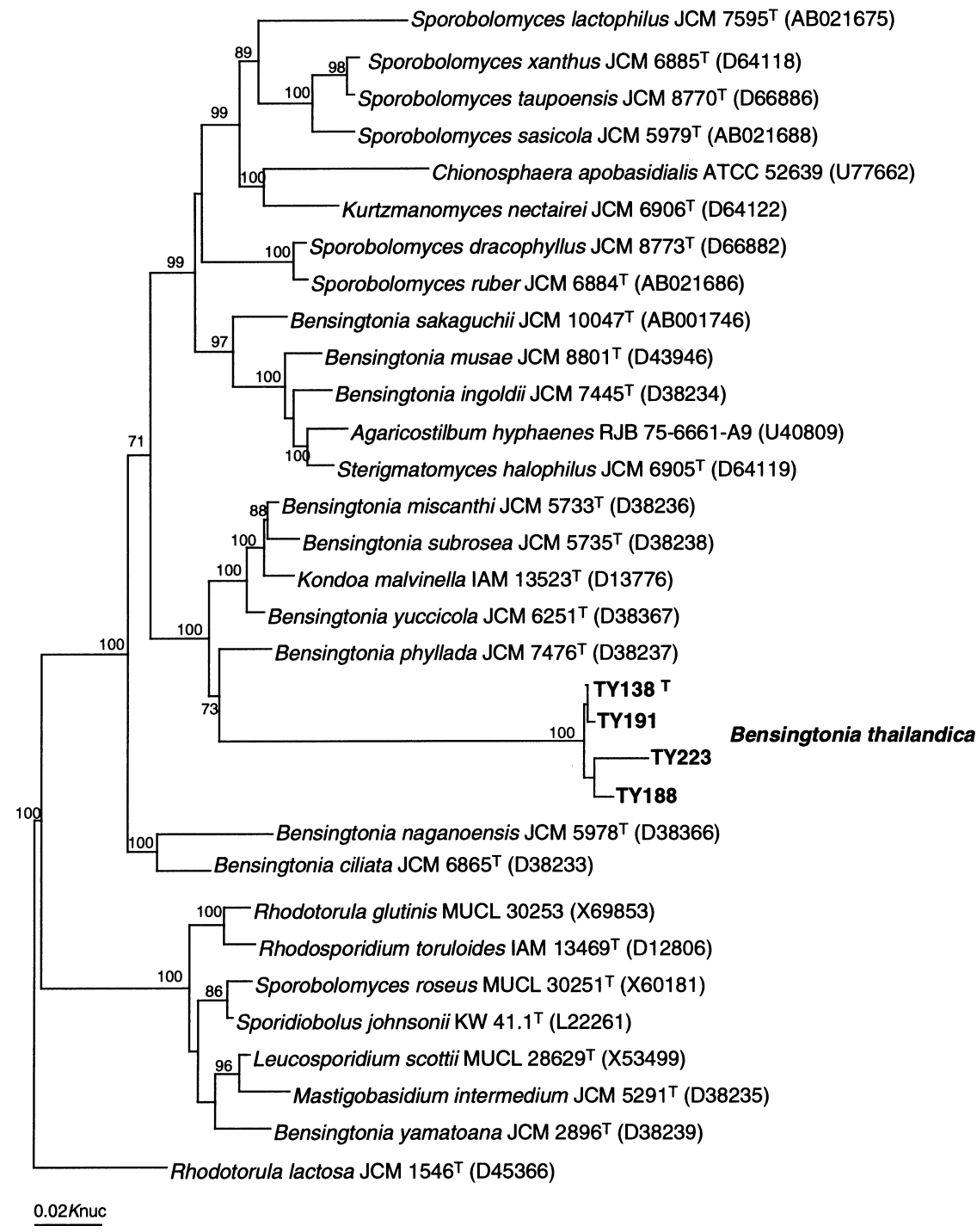

Fig. 1. Phylogenetic positions of four Bensingtonia isolates based on $18 \mathrm{~S}$ rDNA or $18 \mathrm{~S}$ rRNA sequence comparison. The branching pattern was generated by the neighbour-joining method as described in the text. The numbers on the tree indicate bootstrap values greater than $50 \%$.

Table 2. Characteristics differentiating $B$. thailandica from known species + , Positive; -, negative.

\begin{tabular}{|c|c|c|c|c|c|c|c|c|c|c|c|}
\hline Characteristic & B. thailandica & B. ciliata & B. ingoldii & B. miscanthi & B. musae & B. naganoensis & B. phyllada & B. sakaguchii & B. subrosea & B. yamatoana & B. yuccicola \\
\hline \multicolumn{12}{|l|}{ Assimilation of: } \\
\hline L-Sorbose & - & + & - & + & + & - & + & - & + & - & + \\
\hline Sucrose & + & - & + & + & - & + & + & - & + & + & - \\
\hline Cellobiose & + & - & + & + & - & + & + & + & + & - & + \\
\hline Trehalose & + & + & + & + & + & - & + & + & + & + & + \\
\hline Lactose & - & - & + & + & - & - & + & + & + & - & - \\
\hline Melibiose & + & - & + & - & - & + & - & - & - & - & - \\
\hline Raffinose & + & - & + & + & - & + & - & - & + & - & - \\
\hline DNA $\mathrm{G}+\mathrm{C}$ content $(\mathrm{mol} \%)$ & $47 \cdot 1-47 \cdot 9$ & $46 \cdot 1^{*}$ & $56 \cdot 0^{*}$ & $48 \cdot 5^{*}$ & $52 \cdot 3^{*}$ & $53 \cdot 7^{*}$ & $45 \cdot 9 *$ & $52 \cdot 6-52 \cdot 8 \dagger$ & $45 \cdot 5^{*}$ & $51 \cdot 4^{*}$ & $44 \cdot 5^{*}$ \\
\hline
\end{tabular}

* Data from Takashima et al. (1995b).

$\dagger$ Data from Sugita et al. (1997).

acidum 5-ketogluconicum (varium), acidum succinicum, acidum DL-lacticum (varium) et acidum citricum assimilantur, at non L-sorbosum, lactosum, inulinum, $D$ xylosum, L-arabinosum, D-arabinosum, D-ribosum, $L$ - rhamnosum, ethanolum, erythritolum, ribitolum, methyl $\alpha$-D-glucosidum, salicinum, glucono- $\delta$-lactonum, inositolum, acidum D-glucuronicum nec acidum D-galacturonicum. Kalium nitricum et natrium nitricum assimi- 

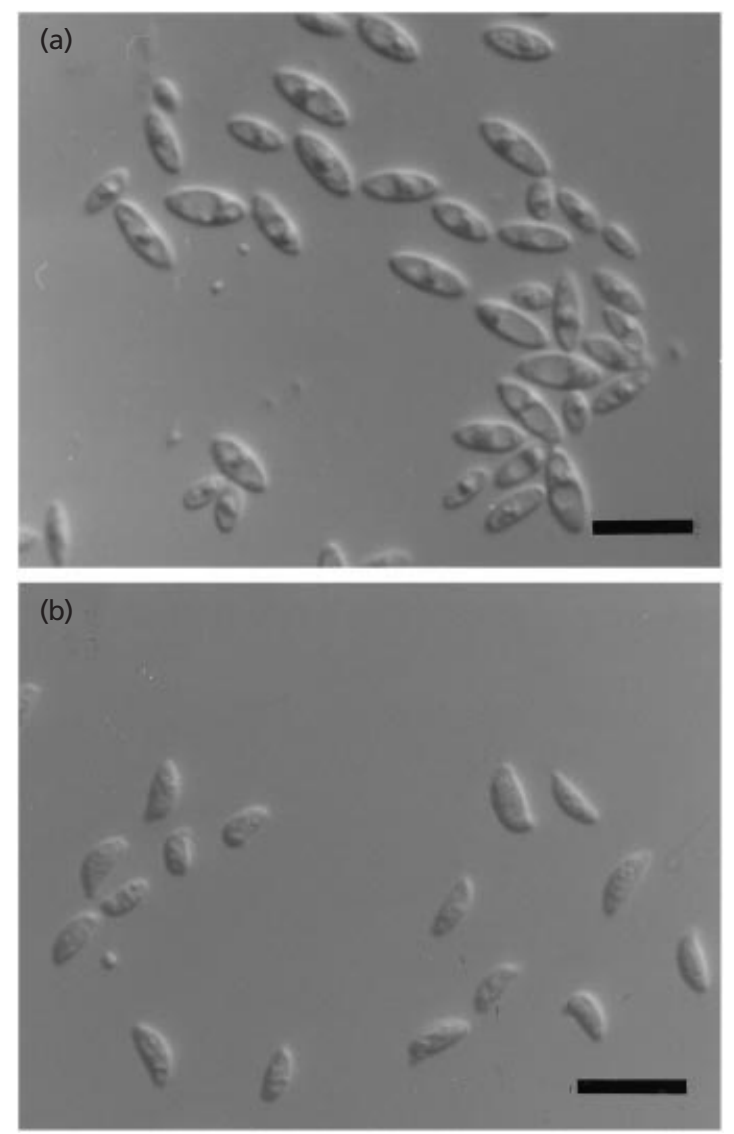

Fig. 2. Photomicrographs of $B$. thailandica $T Y-138^{\top}$ (= JCM $10651^{\top}$ ). (a) Vegetative cells grown on YM agar after $5 \mathrm{~d}$ at $25^{\circ} \mathrm{C}$. (b) Ballistoconidia produced on corn meal agar after $7 \mathrm{~d}$ at $17^{\circ} \mathrm{C}$. Bars, $10 \mu \mathrm{m}$.

lantur at non ethylaminum, L-lysinum nec cadaverinum. Ad crescentiam thiaminum necessarium est. $G+C$ acidi deoxyribonucleati $47 \cdot 1-47 \cdot 9 \mathrm{~mol} \%$ (per HPLC). Ubiquinonum majus Q-9. Typus stirps TY-138 ${ }^{\mathrm{T}}$ ex folio Cratoxylum maingayi, Nakhon Ratchasima Province, Thailand, isolata est. In collectionibus culturarum quas Japan Collection of Microorganisms, Wako, Saitama, sustentant, no. JCM 10651 deposita et in collectionibus culturarum quas Thailand Institute of Scientific and Technological Research, Chatuchak, Bangkok, sustentant, no. TISTR 5733 sunt.

\section{Description of Bensingtonia thailandica sp. nov. Fungsin, Hamamoto \& Nakase}

Bensingtonia thailandica (thai'lan.di.ca. M.L. adj. thailandica referring to Thailand where the 10 strains were isolated).

After $3 \mathrm{~d}$ at $25^{\circ} \mathrm{C}$ in YM broth (Difco), the cells are ovoidal to ellipsoidal $(2 \cdot 0-3 \cdot 0 \times 5 \cdot 0-8 \cdot 0 \mu \mathrm{m})$, single or in pairs (Fig. 2a). A sediment and an incomplete ring are formed after 1 month. After 1 month at $17^{\circ} \mathrm{C}$ on YM agar, streak cultures are pale yellowish/cream, dull to shiny and smooth. The margin is entire. True hyphae or pseudohyphae are not formed in Dalmau plate cultures on cornmeal agar (Difco). Ballistoconidia are produced abundantly on cornmeal agar and YM agar. They are reniform, allantoidal or ellipsoidal, (3.0-4.0 $\times 7 \cdot 0-8 \cdot 0 \mu \mathrm{m})$ (Fig. 2b). Does not ferment D-glucose. Assimilate D-glucose, galactose (variable), sucrose, maltose, cellobiose, trehalose, melibiose, raffinose, melezitose, soluble starch, glycerol (variable), galactitol (variable), D-mannitol (variable), D-glucitol (variable), 2-ketogluconic acid (variable), 5-ketogluconic acid (variable), succinic acid, DLlactic acid (variable) and citric acid. Do not assimilate the carbon of L-sorbose, lactose, inulin, D-xylose, Larabinose, D-arabinose, D-ribose, L-rhamnose, ethanol, erythritol, ribitol, methyl $\alpha$-D-glucoside, salicin, glucono- $\delta$-lactone, inositol, D-glucuronic acid and Dgalacturonic acid. Does not assimilate the following nitrogen sources: ethylamine, L-lysine and cadaverine. Assimilation of nitrate and nitrite is positive. Thiamine is required for growth. Growth does not occur on $50 \%$ $(\mathrm{w} / \mathrm{w})$ glucose-yeast extract agar. No starch-like substance is produced. Does not liquefy gelatin. Urease activity is positive. The diazonium blue $\mathrm{B}$ reaction is positive. The major ubiquinone is $\mathrm{Q}-9$. The $\mathrm{G}+\mathrm{C}$ content of the nuclear DNA is $47 \cdot 1-47.9 \mathrm{~mol} \%$, as determined by HPLC. Type strain TY $-138^{\mathrm{T}}$ was isolated from a dead leaf of Cratoxylum maingayi in a tropical rain forest of Sakearat Environmental Research Station in Nakhon Ratchasima Province, Thailand. This strain has been deposited in the Japan Collection of Microorganisms (JCM), Riken, Wako, Saitama, Japan, as strain JCM $10651^{\mathrm{T}}$ and also deposited in the Thailand Institute of Scientific and Technological Research (TISTR), Chatuchak, Bangkok, Thailand, as strain $5733^{\mathrm{T}}$. The other 9 strains examined have also been deposited in the JCM and the TISTR as JCM 10652/TISTR 5734 (TY-173), JCM 10653/TISTR 5735 (TY-180), JCM 10654/TISTR 5736 (TY-181), JCM 10655/TISTR 5737 (TY-188), JCM 10656/TISTR 5738 (TY-190), JCM 10657/ TISTR 5739 (TY-191), JCM 10658/TISTR 5740 (TY223), JCM 10659/TISTR 5741 (TY-262) and JCM 10660/TISTR 5742 (TY-361).

B. thailandica can be distinguished from the other four known species in the same cluster of the $18 \mathrm{~S}$ rDNAbased tree, B. miscanthi, B. phyllada, B. subrosea and $B$. yuccicola, and from the type species of the genus Bensingtonia, B. ciliata, on the basis of the assimilation of melibiose and the lack of assimilation of L-sorbose (Table 2). The differences in the $\mathrm{G}+\mathrm{C}$ content between $B$. thailandica and the other five known species in the genus, Bensingtonia ingoldii, Bensingtonia musae, Bensingtonia naganoensis, Bensingtonia sakaguchii and Bensingtonia yamatoana, is significant enough to discriminate it from these species (Table 2).

\section{ACKNOWLEDGEMENTS}

This study was performed in the period 1995-1999 through Special Coordination Funds of the Science and Technology Agency of the Japanese Government. We are indebted to 
Mrs Tippan Sadakorn, BK Herbarium, Department of Agriculture, Ministry of Agriculture and Cooperative, Bangkok, Thailand, for identification of plants. We also thank Dr Worapot Suntornsuk, Department of Microbiology, King Mongkut Institute of Technology (Tonburi), Bangkok, Thailand, for his kind help in collecting of plant samples.

\section{REFERENCES}

Boekhout, T. \& Nakase, T. (1998). Bensingtonia Ingold emend. Nakase \& Boekhout. In The Yeasts, a Taxonomic Study, 4th edn, pp. 723-730. Edited by C. P. Kurtzman \& J. W. Fell. Amsterdam: Elsevier.

Cech, T. R. (1988). Conserved sequences and structures of group I introns: building and active site for RNA catalysis - a review. Gene 73, 259-271.

Felsenstein, J. (1985). Confidence limits on phylogenies: an approach using the bootstrap. Evolution 39, 783-791.

Felsenstein, J. (1995). PHYLIP (phylogeny inference package), version 3.57c. Seattle: Department of Genetics, University of Washington.

Hamamoto, M. \& Nakase, T. (1995). Ballistosporous yeasts found on the surface of plant materials collected in New Zealand. 1. Six new species in the genus Sporobolomyces. Antonie Leeuwenhoek 67, 151-171.

Hamamoto, M. \& Nakase, T. (2000). Phylogenetic analysis of the ballistoconidium-forming yeast genus Sporobolomyces based on 18S rDNA sequences. Int $J$ Syst Evol Microbiol 50, 1373-1380.

Ingold, C. T. (1986). Bensingtonia ciliata gen. et sp. nov., a ballistosporic fungus. Trans Br Mycol Soc 86, 325-328.

Komagata, K. \& Nakase, T. (1967). Microbiological studies on frozen foods. V. General properties of yeasts isolated from frozen foods. Shokuhin Eiseigaku Zasshi 8, 53-57 (in Japanese).

Nakase, T. \& Boekhout, T. (1988). Emendation of the genus Bensingtonia Ingold. J Gen Appl Microbiol 34, 433-437.

Nakase, T. \& Suzuki, M. (1985). Ballistospore-forming yeasts found on the surface of the Japanese rice plant, Oryza sativa $\mathrm{L}$. J Gen Appl Microbiol 31, 457-474.

Nakase, T. \& Suzuki, M. (1986). Bullera megalospora, a new species of yeast forming large ballistospores isolated from dead leaves of Oryza sativa, Miscanthus sinensis and Sasa sp. in Japan. J Gen Appl Microbiol 32, 225-240.

Nakase, T. \& Takashima, M. (1993). A simple procedure for the high frequency isolation of new taxa of ballistosporous yeasts living on the surface of plants. RIKEN Rev 3, 33-34.

Saitou, N. \& Nei, M. (1987). The neighbor-joining method: a new method for reconstructing phylogenetic trees. Mol Biol Evol 4, 406-425.

Sugita, T., Takashima, M., Hamamoto, M., Budhaka, P. \& Nakase, T. (1997). Bensingtonia sakaguchii sp. nov. isolated from a leaf of Bischofia javanica in the Ogasawara Islands. J Gen Appl Microbiol 43, 231-235.

Suzuki, M. \& Nakase, T. (1988). The distribution of xylose in the cells of ballistosporous yeasts - application of high performance liquid chromatography without derivatization to the analysis of xylose in whole cell hydrolysates. J Gen Appl Microbiol 34, 95-103.

Takashima, M., Suh, S.-O. \& Nakase, T. (1995a). Phylogenetic relationships among species of the genus Bensingtonia and related taxa based on the small subunit ribosomal DNA sequences. J Gen Appl Microbiol 41, 131-141.

Takashima, M., Suh, S.-O. \& Nakase, T. (1995b). Bensingtonia musae sp. nov. isolated from a dead leaf of Musa paradisiaca and its phylogenetic relationship among basidiomycetous yeasts. J Gen Appl Microbiol 41, 143-151.

Thompson, J. D., Higgins, D. G. \& Gibson, T. J. (1994). CLUSTAL $\mathrm{W}$ : improving the sensitivity of progressive multiple sequence alignment through sequence weighting, position-specific gap penalties and weight matrix choice. Nucleic Acids Res 22, 4673-4680.

White, T. J., Bruns, T., Lee, S. \& Taylor, J. W. (1990). Amplification and direct sequencing of fungal ribosomal RNA genes for phylogenetics. In PCR Protocols, pp. 315-322. Edited by M. Innis, D. Gelfand, J. J. Sninsky \& T. J. White. San Diego: Academic Press.

Yamada, Y. \& Kondo, K. (1973). Coenzyme Q system in the classification of the yeast genera Rhodotorula and Cryptococcus and the yeast-like genera Sporobolomyces and Rhodosporidium. J Gen Appl Microbiol 19, 59-77.

Yarrow, D. (1998). Methods for the isolation, maintenance and identification of yeasts. In The Yeasts, a Taxonomic Study, 4th edn, pp. 77-100. Edited by C. P. Kurtzman \& J. W. Fell. Amsterdam: Elsevier. 